\title{
The use of autologous fat grafts in breast surgery: A literature review
}

\author{
Yalcin Bayram ${ }^{1}$, Melihcan Sezgic ${ }^{2}$, Percin Karakol ${ }^{2}$, Mehmet Bozkurt', Gaye Taylan Filinte ${ }^{3}$ \\ ${ }^{1}$ Department of Plastic, Reconstructive and Aesthetic Surgery, Amerikan Estetik Clinic, Istanbul; ${ }^{2}$ Department of Plastic, Reconstructive and \\ Aesthetic Surgery, Bagcilar Training and Research Hospital, Istanbul; ${ }^{3}$ Department of Plastic, Reconstructive and Aesthetic Surgery, Kartal \\ Training and Research Hospital, Istanbul, Turkey
}

Autologous fat injection was first described roughly a century ago and has been used in surgery ever since. In addition to its use in many surgical fields, it is also frequently used for both aesthetic and reconstructive purposes in breast surgery. Since the application of fat grafting in breast surgery has steadily increased, studies investigating its reliability have simultaneously become increasingly common. Previous studies have reported that the use of fat grafting in breast surgery is reliable, but some pending questions remain about its routine use. In order to use fat grafts successfully in breast surgery, it is necessary to be familiar with the structure and content of adipose tissue, the efficacy of adipose stem cell-enriched fat grafts, the oncological safety of fat grafts, and the problems that may occur in the radiological follow-up of patients who undergo fat grafting procedures. In this literature review, we aim to discuss the use of fat grafts in breast surgery by investigating these common problems.

Keywords Adipose tissue / Autografting / Breast neoplasms / Mammaplasty / Mesenchymal stem cells
Correspondence: Melihcan Sezgic Department of Plastic, Reconstructive and Aesthetic Surgery, Bagcilar Training and Research Hospital, Merkez Mahallesi Dr. Sadik Ahmet Caddesi Bagcilar, Istanbul 34100, Turkey

Tel: +90-212-440-40-00

Fax: +90-212-440-42-42

E-mail:mlh_s@yahoo.com

We would like to thank our colleagues in the clinic who helped us for literature research in this study.

Received: March 11, $2019 \bullet$ Revised: October 18, $2019 \bullet$ Accepted: November 8, 2019

pISSN: 2234-6163 • elSSN: 2234-6171 • https://doi.org/10.5999/aps.2019.00416• Arch Plast Surg 2019;46:498-510

\section{INTRODUCTION}

Autologous fat transfer, which has been commonly used in plastic surgery in recent decades, was first performed by Neubauer in 1893 for the repair of facial defects [1,2]. Although more than a century has passed since then, various problems related to fat grafts still await solutions, while numerous other questions remain unanswered. Theoretically, autologous fat grafts may constitute an ideal source for the repair of congenital, developmental or acquired soft tissue defects. They have multiple advantages in comparison with other filling materials and implants; specifically, they are biocompatible, cost-effective and can be obtained from several donor sites in the human body that are suitable for fat harvesting. An additional advantage is that fat grafting procedures can be repeated at certain time intervals. Moreover, the lipo-contouring of the donor site may be perceived as a cosmetic advantage, which makes the procedure appealing for patients.

Despite these advantages, the greatest disadvantage limiting the use of fat grafts is the unpredictability of the final outcome and the dependence of graft volume on fat retention and growth. The final result is associated with the density of the transferred viable cells and the ratio of graft adherence. The most important factor that promotes the survival of fat grafts is neovascularization of the grafts [3]. Until neovascularization is complete, fat grafts are nourished through diffusion from the receiving bed. For this reason, larger grafts are at a higher risk of necrosis, since 
nutrients received through diffusion can only penetrate up to 1.5 $\mathrm{mm}$ inside the border of a fat graft. Thus, the fat cells at the centre of the graft, which are more sensitive to hypoxia, are prone to cell death. As a result, fat necroses, fat cysts and microcalcifications are often observed after the application of fat grafts $[3,4]$.

Breast cancer is the most common malignancy in women, accounting for approximately $30 \%$ of malignancies in women according to recent statistics [5]. Fortunately, with early detection and treatment, the mortality rate of breast cancer has decreased. Fat grafts have a long history of use in breast surgery for reconstructive purposes. In 1895, Czerny used fat grafts for the first time to repair a postmastectomy defect $[2,6]$. Although the use of autologous fat grafts for breast augmentation is a theoretically appealing, low graft durability rates have been a persistent problem. These problems have spurred the development of breast implants and filling materials other than autologous fat. However, the restriction imposed in 1987 by the American Society of Plastic Surgeons on procedures involving fat transfer to the breast has constituted a distinct obstacle to developments in this area $[2,7,8]$. The use of fat grafts in large volumes for the purposes of breast augmentation may lead to radiological microcalcifications in the postoperative period. The reason for the restriction was the inability to distinguish the microcalcifications caused by fat grafts from breast cancer using the imaging techniques of the day [8]. This restriction was lifted in 2007 and studies on fat grafts have gained pace [9]. Nonetheless, many unanswered questions remain regarding the use of fat grafts (Table 1). The available data about autologous fat grafting in aesthetic breast surgery consist of only case reports, case studies and retrospective reviews. This literature review aims to focus on the use of fat grafts in breast surgery, which has recently expanded in popularity.

\section{USE OF FAT GRAFTS IN BREASTS}

Although fat grafts can be used in the face, body, extremities and breast, they are most frequently used in the face and breasts for aesthetic purposes [10-14]. Today, fat grafts are used for the cosmetic augmentation of hypoplastic breasts [8,15-21], in congenital anomalies (tuberous breasts and Poland syndrome) $[17,22,23]$ and in reconstructions due to breast cancer $[17,18$, 24-27]. The results strongly depend on the technique and the experience of the surgeon [9]. In literature, graft loss rates have been reported to range between $20 \%$ and $90 \%$ over a 1 -year time period [2,28-30]. Choi et al. [31,32] used three-dimensional photography to observe graft persistence and reported that the graft survival rate was $40 \%$ to $50 \%$; interestingly, the transfer of greater volumes was found to lead to greater persis- tence. Although advanced techniques used in fat transfer have led to improved results, there are still no standardized methods for fat harvesting, preparation and injection into the recipient site [33]. In order to increase the survival rate of fat grafts, various modifications have been planned for every step, including the selection of the donor site, the harvesting and preparation of the graft, the injection technique and postoperative care. The most prominent modifications are cell-assisted lipotransfer (CAL) [15], which involves transferring the fat graft together with adipocyte stem cells, and the combined transfer method with platelet-rich plasma [34]. Various reviews have focused on techniques of fat graft transfer $[2,35]$.

The use of autologous fat for breast augmentation may be revolutionary. Extensive use of this method may replace the use of breast implants in mammaplasty. However, the reports that fat grafts may cause breast cancer have led to a cautious approach to autologous fat grafting. In order to approve the use of autologous fat in mammaplasty, it is necessary to ensure that this claim is unfounded. There are two oncological problems concerning fat grafts applied to the breast. First, since the fat undergoes varying levels of nodule formation and calcifications, it may be confused with breast cancer on a physical examination and radiological imaging and thereby hinder an early diagnosis of breast cancer. Second, fat grafts may themselves produce local oestrogen in stromal-epithelial interactions either by means of aromatase originating from the adipocytes or through mediators known as adipokines, thereby facilitating the development of breast cancer $[33,36-40]$. The information in the literature on

\section{Table 1. Pending questions to be answered about fat grafts}

Survival of fat grafts

1. How can we predict the survival rate of fat grafts?

2. Does the choice of the donor area affect the survival of the graft?

3. Which technique should be used to harvest the graft?

4. How should the graft be prepared in order to achieve maximum graft survival?

5. Which is the best injection technique?

6. Do adipose stem cells carry hope for the future?

Oncological safety of fat grafts

1. Does fat grafting increase the risk of breast cancer?

2. Do fat grafts mask malignant lesions radiologically?

3. Should patients who have undergone fat grafting be offered a follow-up procedure different from the normal population?

4. If a suspicious lesion is detected in a breast that has undergone fat grafting, how should the lesion be evaluated?

5. Is there any way to distinguish microcalcifications from breast cancer on mammography?

6. Which radiological methods are most suitable for follow-up? 
this topic is conflicting because the extant studies have had disadvantages such as a small number of patients and short, nonstandardized follow-up durations $[2,33]$. Therefore, our current knowledge is insufficient to clarify this issue [15].

\section{INFLUENCE OF ENDOCRINE AND PARACRINE PATHWAYS ON THE ADIPOSE TISSUE MICROENVIRONMENT}

Autologous fat is inherently distinct from other filling materials and silicone implants for several reasons. First, the transferred fat is actually viable tissue, with the potential to influence the microenvironment of the transplant site through paracrine and endocrine pathways [39-42]. From the point of view of the breast, it is known that the mammary epithelium is within an area of stroma that includes adipocytes. In order to continue its existence, the mammary epithelium needs this stromal support. The greater part of the stroma supplying this life support is made of adipocytes. Initially, adipocytes were considered as cells that only stored energy, but within the last 10 years, it has been discovered that they act as endocrine cells by synthesising molecules known as adipokines. Adipokines are a heterogeneous group that includes hormones, growth factors, chemokines and pro-inflammatory molecules [39,43-46]. Numerous experimental studies have demonstrated that adipocytes support cancer formation, invasion, migration and resistance to treatment through various paracrine and endocrine pathways [37-44,47-51]. A chronological comparison of some of these experimental studies is presented in Table $2[36,37,43,44,49$ 54]. Regarding the growth of tumor tissue, there is evidence indicating that the tissue adjacent to a tumor is not only a passive supporting tissue, but plays an active role in tumor progression. The adipose tissue of the breast plays a major role in these interactions between a tumor and the stroma $[15,33]$.

Since the abovementioned experimental studies suggest that adipose tissue transfer may affect the formation, prognosis and treatment of breast cancer, the following important features of adipose tissue must be clarified in order to understand the usability of fat grafts in breast surgery: (1) The structure and content of adipose tissue in the human body; (2) The isolation of adipose-derived stromal/stem cells (ADSCs); or (3) The oncological safety of autologous fat transfer to the breast.

\section{The structure and content of adipose tissue in the human body}

As is generally known, mammals have two different types of adipocytes (white and brown). There is also a third type of beige (brown/white) adipocyte that is closely linked to white adipocytes [55]. From a general point of view, white fat serves for energy storage and is involved with gaining and losing weight, while the main purpose of brown fat is thermoregulation. Adults have very little brown fat tissue. At the beginning of the 20th century, fat tissue was believed to consist of cells filled with fat drops, and its purpose was supposed to be limited to preserving body heat and mechanically supporting certain tissues [56]. It was even thought that fat storage within the body was a passive process independent from the general energy metabolism of the body. Later studies on lipid metabolism have revealed that fat tissue is not as insignificant as imagined; instead, it is rather important because fat storage and metabolism are regulated by neural and endocrine factors [56,57]. In a literature review, Lafontan [56] presents detailed insights into the historical timeline of the biology of fat tissue. White fat tissue consists not only of fat-storing adipocytes, but also a considerable amount of supporting cells surrounding the adipocytes. This heterogeneous cell group is called the stromal vascular fraction (SVF). The SVF is composed of ADSCs, vascular endothelial cells and their precursors, lymphocytes, macrophages and fibroblasts. Mature adipocytes are spherical and contain a single fat drop in the cytoplasm, which forms the centre of the cell $[39,45,58]$.

Another important aspect of studies on adipose tissue is the storage areas of adipose tissue in the human body. Traditionally, two major fat storage areas have been recognized: visceral fat tissue and subcutaneous fat tissue. It is known that the amount of visceral fat is more closely related to obesity-related disorders such as type II diabetes and cardiovascular diseases than the amount of subcutaneous fat tissue. This may have interesting implications for the health effects of adipose tissue in the human breast. Mammary tissue consists of mainly myoepithelial and luminal epithelial cells within the mammary fat pad, which is mainly composed of fibroblasts and adipocytes. Vascular and lymphatic system cells are also observed to be dispersed among these cells $[45,58]$.

The physiology of adipose tissue has received an increased amount of attention because obesity is becoming an increasingly major health problem. Obesity is also an independent negative prognostic factor for breast cancer, although no direct link between obesity and breast cancer has yet been established [41,59-62]. However, obesity can affect breast cancer risk in different manners. Kerr et al. [63] suggested that high body mass index is related with a lower risk of premenopausal breast cancer, but an increased risk after menopause. Furthermore, dysregulation of sex hormone metabolism, disruption of insulin signalling and alterations of adipokine expression are pathways through which obesity promotes breast carcinogenesis [64]. 
Table 2. Chronological order of experimental studies performed

\begin{tabular}{|c|c|c|c|}
\hline Author & Title (year of the study) & Design of the study & Conclusion \\
\hline Rahimi [50] & $\begin{array}{l}\text { Role of hepatocyte growth } \\
\text { factor in breast cancer: } \\
\text { a novel mitogenic factor } \\
\text { secreted by adipocytes } \\
\text { (1994) }\end{array}$ & $\begin{array}{l}\text { Study animal: murine } \\
\text { Fat cell source: 3T3-L1 adipocytes obtained through culture of the 3T3- } \\
\text { L1 preadipocyte cell line } \\
\text { Tumor cell: SP1 cell line (mammary adenocarcinoma) } \\
\text { Mitotic activity, hepatocyte growth factor (HGF) levels and HGF receptor } \\
\text { levels, which are thought to influence this activity, were analysed in } \\
\text { cells obtained by addition of the SP1 cell line into the conditioned } \\
\text { medium obtained from the 3T3-L1 cell line }\end{array}$ & $\begin{array}{l}\text { HGF is released by the 3T3-L1 adipocytes } \\
\text { and acts through the paracrine } \\
\text { stimulation of SP1 cell growth. }\end{array}$ \\
\hline lyengar [43] & $\begin{array}{l}\text { Adipocyte-secreted factors } \\
\text { synergistically promote } \\
\text { mammary tumorigenesis } \\
\text { through induction of } \\
\text { anti-apoptotic } \\
\text { transcriptional programs } \\
\text { and proto-oncogene } \\
\text { stabilization (2003) }\end{array}$ & $\begin{array}{l}\text { Study animal: athymic nude mice } \\
\text { In vitro: 3T3-L1 murine adipocytes } \\
\text { Tumor cell: oestrogen receptor (+) (ER-positive) MCF-7 breast cancer } \\
\text { cells and ER-negative SUM-159PT breast cancer cells; The factors } \\
\text { secreted by the adipocytes and their effects were evaluated through } \\
\text { methods such as microarray analysis, FACS analysis and luciferase } \\
\text { reporter assay } \\
\text { In vivo: ER-negative SUM-159PT breast cancer cells were transplanted } \\
\text { together with and separately from the 3T3-L1 adipocytes }\end{array}$ & $\begin{array}{l}\text { The factors secreted by the adipocytes } \\
\text { increased the development of mammary } \\
\text { tumors. This occurred through the } \\
\text { stabilization of pro-oncogenes and } \\
\text { prevention of apoptosis in the tumor } \\
\text { cells. }\end{array}$ \\
\hline Manabe [36] & $\begin{array}{l}\text { Mature adipocytes, but not } \\
\text { preadipocytes, promote } \\
\text { the growth of breast } \\
\text { carcinoma cells in } \\
\text { collagen gel matrix } \\
\text { culture through cancer- } \\
\text { stromal cell interactions } \\
\text { (2003) }\end{array}$ & $\begin{array}{l}\text { Study animal: MMT060562 of ER-negative Wistar rat origin } \\
\text { Tumor cell: oestrogen receptor (+) (ER+) MCF-7 of human origin, ZR75- } \\
1 \text { and T47-D with MMT060562 of ER-negative rat origin } \\
\text { Fat cell source: fat tissue with cancer cells obtained from male Wistar } \\
\text { rats and mature adipocytes and preadipocytes cultured in a three- } \\
\text { dimensional collagen gel culture system }\end{array}$ & $\begin{array}{l}\text { Mature adipocytes enhanced the growth of } \\
\text { ER-positive breast cancer cells. This } \\
\text { occurred through the interaction } \\
\text { between the cancer cell and the stromal } \\
\text { cells. Preadipocytes did not have such } \\
\text { an effect. }\end{array}$ \\
\hline Yu [37] & $\begin{array}{l}\text { Mesenchymal stem cells } \\
\text { derived from human } \\
\text { adipose tissues favor } \\
\text { tumor cell growth in vivo } \\
\text { (2007) }\end{array}$ & $\begin{array}{l}\text { Study animal: BALB/c nude mice. Injections were made to the } \\
\text { intracranial area and under the skin of the study animal } \\
\text { Tumor cell: H460 and U87MG } \\
\text { Fat cell source: cultured human adipocyte stem cells (hASCs) }\end{array}$ & $\begin{array}{l}\text { hASCs enhanced in vivo tumor growth. } \\
\text { This is explained as a consequence of the } \\
\text { hASCs increasing the survival rate of the } \\
\text { transplanted tumor cells, decreasing } \\
\text { apoptosis and enhancing their } \\
\text { proliferation. }\end{array}$ \\
\hline Walter [44] & $\begin{array}{l}\text { Interleukin-6 secreted } \\
\text { from adipose stromal } \\
\text { cells promotes migration } \\
\text { and invasion of breast } \\
\text { cancer cells (2009) }\end{array}$ & $\begin{array}{l}\text { Study animal: mice with immune deficiency } \\
\text { Tumor cell: oestrogen receptor (+) (ER-positive) MCF- } 7 \text { breast cancer } \\
\text { cells and ER-negative MDA-MB-231 breast cancer cells; The migration } \\
\text { and invasion of the cancer cells was evaluated through the Boyden- } \\
\text { Chamber cell migration assay and Matrigel-based cell invasion assay } \\
\text { In vitro: adipose stromal cells (ASCs) obtained from cancer-free } \\
\text { individuals } \\
\text { In vivo: transplanted only within the renal capsules of mice with immune } \\
\text { deficiency together with MDA-MB-231 tumor cells or ASCs }\end{array}$ & $\begin{array}{l}\text { The results obtained by processing the } \\
\text { cancer cells with the ASCs showed that } \\
\text { the ASCs increased the migration and } \\
\text { invasion of the cancer cells. The cofilin-1 } \\
\text { pathway and the paracrine signals of the } \\
\text { ASCs, such as interleukin-6, were } \\
\text { observed to play an important role in this } \\
\text { outcome. }\end{array}$ \\
\hline Martin-Padura [49] & $\begin{array}{l}\text { The white adipose tissue } \\
\text { used in lipotransfer } \\
\text { procedures is a rich } \\
\text { reservoir of CD34+ } \\
\text { progenitors able to } \\
\text { promote cancer } \\
\text { progression (2012) }\end{array}$ & $\begin{array}{l}\text { Study animal: female non-obese diabetic (NOD) scid gamma (NSG) mice, } \\
6 \text { to } 9 \text { weeks old } \\
\text { Fat cell source: human white fat cells (human WAT) obtained from breast } \\
\text { cancer patients and used in their reconstruction } \\
\text { Tumor cell: MDA-MB- } 436 \text { and HCC1937 triple-negative breast cancer } \\
\text { cells } \\
\text { In vitro: CD45-CD34+ progenitor cells, purified } \\
\text { In vivo: cancer cells injected together with the CD45-CD34+ cells and } \\
\text { separately into the mammae of the study animals }\end{array}$ & $\begin{array}{l}\text { The CD45-CD34+ endothelial progenitor } \\
\text { cells were abundant in human WAT. The } \\
\text { co-injection of human WAT-CD34 }{ }^{+} \text {cells } \\
\text { from lipotransfer procedures significantly } \\
\text { increased tumor growth and metastases } \\
\text { in breast cancer models. }\end{array}$ \\
\hline Kamat [51] & $\begin{array}{l}\text { Human adipose-derived } \\
\text { mesenchymal stromal } \\
\text { cells may promote } \\
\text { breast cancer } \\
\text { progression and } \\
\text { metastatic spread } \\
\text { (2015) }\end{array}$ & $\begin{array}{l}\text { Study animal: 6-week-old nu/nu mice } \\
\text { Fat cell source: adipose-derived mesenchymal stromal cells (AD-MSCs) } \\
\text { isolated from healthy female abdominal lipoaspirates } \\
\text { Tumor cell: MDA-MB-231 (MDA) and MCF-7 (MCF) cultured in } \\
\text { Dulbecco's Modified Eagle Medium } \\
\text { Co-Culture: the cells were mixed in different concentrations and cultured } \\
\text { for } 8 \text { days. After that, they were injected into animal models (MDA and } \\
\text { MCF separately) }\end{array}$ & $\begin{array}{l}\text { Without AD-MSCs, MDA cells showed } \\
54.5 \% \text { viability, but in those cultured } \\
\text { with AD-MSC }{ }^{\text {high }} \text {, the MDA cell viability } \\
\text { increased to } 95.5 \% \text {. AD-MSCs have the } \\
\text { potential to promote tumor progression } \\
\text { in breast cancer cells. }\end{array}$ \\
\hline
\end{tabular}


Table 2. Continued

\begin{tabular}{|c|c|c|c|}
\hline Author & Title (year of the study) & Design of the study & Conclusion \\
\hline Molto-Garcia [52] & $\begin{array}{l}\text { Effect of human fat graft } \\
\text { on breast cancer } \\
\text { metastasis in a murine } \\
\text { model (2017) }\end{array}$ & $\begin{array}{l}\text { Study animal: } 18 \text { female nude mice aged } 6 \text { weeks } \\
\text { Fat cell source: abdominal lipoaspirate from six adult healthy white } \\
\text { women (only fat grafts, not enriched with ADSCs) } \\
\text { Tumor cell: MDA-MB-468 } \\
\text { In vivo: group A: MDA-MB-468 without human adipose tissuehuman } \\
\text { adipose tissue; Group B: mixed with human adipose tissue; Both were } \\
\text { injected into the left renal capsule }\end{array}$ & $\begin{array}{l}\text { Group A had the shortest survival rate but } \\
\text { no significant differences were found } \\
\text { compared to group B. When human fat } \\
\text { grafts were extracted and handled in the } \\
\text { same way as is done routinely in clinical } \\
\text { practice, autologous fat tissue did not } \\
\text { worsen the prognosis or the course of } \\
\text { the disease. }\end{array}$ \\
\hline Tsuji [53] & $\begin{array}{l}\text { An animal model of local } \\
\text { breast cancer } \\
\text { recurrence in the setting } \\
\text { of autologous fat grafting } \\
\text { for breast reconstruction } \\
(2017)\end{array}$ & $\begin{array}{l}\text { Study animal: 8- to 10-week-old female NSG mice } \\
\text { Fat cell source: female, healthy individuals (only fat grafts, not enriched } \\
\text { with ADSCs) } \\
\text { Tumor cell: BT-474 and MDA-MB-231 breast cancer cell lines. Two } \\
\text { approaches, each with its own control group: (1) cancer cells were } \\
\text { seeded directly into human fat grafts, injected into the mice and } \\
\text { excised at } 6 \text { weeks; (2) a fat graft was injected } 2 \text { weeks after cancer } \\
\text { cell injection }\end{array}$ & $\begin{array}{l}\text { Both approaches; autologous fat grafts } \\
\text { were not a supportive environment for } \\
\text { the growth of tumor cells and may even } \\
\text { have a suppressive effect on tumor cell } \\
\text { proliferation. }\end{array}$ \\
\hline Orbay [54] & $\begin{array}{l}\text { Fat graft safety after } \\
\text { oncologic surgery: } \\
\text { addressing the } \\
\text { contradiction between in } \\
\text { vitro and clinical studies } \\
\text { (2018) }\end{array}$ & $\begin{array}{l}\text { Study animal: female nude mice } \\
\text { In vitro: interaction of breast cancer cells and human ADSCs using a } \\
\text { migration assay chamber } \\
\text { Fat cell source: single healthy human donor } \\
\text { Tumor cell: MDAMB-231 } \\
\text { In vivo: fat grafts, separated into two groups: In the first, the stromal } \\
\text { vascular fraction was isolated, and in the second, the Coleman } \\
\text { technique was used. } 4 \text { Different groups were created (mixed with } \\
\text { cancer cells) }\end{array}$ & $\begin{array}{l}\text { Fat grafting is safe for oncologic breast } \\
\text { reconstruction. However, co-injection of } \\
\text { fat grafts enriched with ADSCs should } \\
\text { be used with caution, at least until } \\
\text { cancer remission can be firmly } \\
\text { established. }\end{array}$ \\
\hline
\end{tabular}

Obesity alters the cellular composition of adipose tissue by influencing the T-lymphocyte concentration of adipose depots. In people with a body mass index lower than $25 \mathrm{~kg} / \mathrm{m}^{2}$, the proportion of $\mathrm{CD}^{+}$and $\mathrm{CD}^{+} \mathrm{T}$ cells in subcutaneous adipose tissue was found to be well below $1 \%$. Conversely, these values approached $4 \%$ to $5 \%$ in severely obese people with a body mass index exceeding $40 \mathrm{~kg} / \mathrm{m}^{2}$ [65]. These findings indicate that in obese people, the adipose tissue contains more inflammationmediating cytokines.

In obesity, the production of a number of inflammation-related adipokines (e.g., tumor necrosis factor-alpha, interleukin-6, haptoglobin and leptin) is increased within adipose tissue [66]. The only exception to this trend is adiponectin, the production of which is decreased [67]. Adiponectin is a growth factor secreted by adipocytes that causes macrophages to change their form from inflammatory to anti-inflammatory (regenerative) [68]. Regenerative macrophages contribute to the formation of new preadipocytes with the help of existing adipocytes in a process known as neoadipogenesis, which is an important step for fat graft survival [69]. Although no study has directly investigated fat graft survival in obese people compared with healthy people, this finding may suggest that fat graft survival could be higher in normal-weight individuals than in obese people.

\section{Isolation of ADSCs}

A ground-breaking study on human fat tissue was published by Zuk et al. in 2001 [70], demonstrating that stem cells could be isolated from human tissue and could differentiate into adipogenic, chondrogenic, myogenic and osteogenic cells. Subsequent studies have shown that ADSCs can also transdifferentiate into various other types of cells [70-78]. Today, there is great scientific and clinical interest in the use of stem cells for a wide spectrum of purposes $[71,79]$. Bone marrow and adipose tissue are frequently used sources of stem cells in regenerative medicine studies. However, obtaining stem cells from the bone marrow causes donor site morbidity and pain. Moreover, since the number of the obtained stem cells is limited, they need to be cultured and expanded to be used for any purpose. Besides being expensive, this culturing process also changes the cell biology $[71,80]$. In contrast, ADSCs can be obtained easily and abundantly through liposuction or the excision of fat tissue. Compared to the bone marrow, 100 to 1,000 times more pluripotent stem cells can be derived from each cubic centimetre of fat tissue. Due to this abundance of ADSCs, there is also no need for tissue culture $[71,72,81]$.

The possibility of obtaining ADSCs in large numbers, has gained attention in the field of regenerative medicine. Regenerative medicine is the subdivision of medicine that deals with the 
use of biomaterials, growth hormones and stem cells to repair, replace or regenerate tissues or organs that are damaged due to injury or disease $[58,82,83]$. Regenerative medicine advances synergistically with developments in biotechnology, as ADSCs have emerged as a focus of increasing interest. Detailed studies have also explored the use of ADSCs in regenerative medicine [58].

When it comes to the application of fat grafts in breast surgery, ADSCs have been increasingly used in combination with fat grafts in recent years with the hope of improving the durability of fat grafts. Inadequate neovascularization is the factor most frequently blamed for the loss of fat grafts $[15,71]$. The use of stem cells aims to achieve better neovascularization. However, inadequate neovascularization is not the only factor leading to the loss of grafted fat tissue. Mechanical damage and membrane damage to the cells and mechanisms such as apoptosis are also contributing factors [71]. Therefore, although fat grafts supported with ADSCs are a distinctly promising development that may improve the durability of grafts, the use of ADSCs is by no means a conclusive solution.

\section{The oncological safety of autologous fat transfer to the breast}

Autologous fat grafting for breast reconstruction or breast augmentation has been gaining popularity in recent years [17]. Lipoinjection is a useful method both for avoiding implant-related complications and for maintaining a natural appearance after surgery. Although it has several advantages, oncological safety is still a major issue that limits its use in breast reconstruction. Lipoaspirate contains numerous ADSCs, which play a major role in graft survival [15]. The main concern about safety is that ADSCs may secrete growth factors that increase the possibility of breast cancer recurrence. Despite the widespread use of fat grafting, the relationship between adipose tissue and breast cancer is still not well established [9].

There are considerable differences in terms of oncological safety between using fat grafts for breast augmentation and using them for reconstruction following oncological surgery. First, when a fat graft is used for breast reconstruction, the injection is made into a high-risk area for cancer development in a patient with established familial, genetic and cellular risk factors. When an injection is performed for cosmetic purposes, the conditions are different because no breast cancer is involved. Second, the importance of postoperative follow-up varies between these patient groups. Since the patients who receive breast reconstruction with fat grafts due to cancer will be under much closer observation, the evaluation of radiological findings or a palpable mass that may be confused with breast cancer is of much greater importance. However, this is also an advantage, since these pa- tients are closely followed-up to protect against the spread and relapse of breast cancer.

Third, there are discrepancies in the literature between clinical and experimental studies of the oncological safety of fat grafting. Although fat grafts have been shown to cause tumor formation in previous experimental studies, the extant clinical studies are insufficient to show that locoregional recurrence is higher in patients who have undergone autologous fat injections [84]. The experimental studies presented on Table 2 demonstrate that adipocytes increase the risk of development, invasion and progression of breast cancer and its resistance to treatment. However, direct extrapolation of data from experimental studies to the clinical setting may not be applicable and will lead to misinterpretation. Indeed, data from clinical patient series do not correlate with the results from experimental studies. Several reasons for this discrepancy may exist, as follows: (1) There are differences between the experimental animals and humans in terms of the cells constituting the breast tissue. For instance, although the breast tissue is primarily composed of adipocytes in rodents, in the human breast, the adipose tissue is enmeshed with fibroblasts and connective tissue $[39,46]$. (2) When fat grafts are transferred to the breast, they do not only contain adipocytes, but also other cells within the SVF. In other words, experimental models do not directly reflect the fat grafts used in clinical applications. It may be a more accurate approach to regard fat grafts as fat transfer, rather than as adipocyte transfer. (3) When fat grafts are injected into the breast, the graft material is transferred to areas where fat tissue already exists. These injections are usually made around the gland, below the gland and into the pectoral muscle. Even if intraglandular injections are performed, they are made in very small amounts $[15,17,33]$. This technique may serve to reduce the potential oncological risk posed by interactions between breast and adipose tissue [39].

\section{Clinical studies}

Autologous fat grafting in breast surgery seems to be clinically safe, but experimental studies have shown that fat grafting may increase the likelihood of recurrence. Since fat grafting has become considerably more common in recent years, the oncological safety of fat grafts has emerged as an urgent question. The number of published clinical studies on this issue has been increasing in recent years. Several researchers agree that fat transfer into the breast is a reliable method [9,15-18,33,85-90]. However, it should be noted that studies on patient groups where lipofilling has been performed for the purposes of breast augmentation are based mainly on the authors' opinions, due to the inadequate patient number and short duration of follow-up. In 2013, Petit et al. [91] performed a matched cohort study 
comparing patients with breast cancer who had undergone fat grafting surgery with a control group. Their study indicated that fat injection is a oncologically reliable method even in patients with breast cancer. Nevertheless, they pointed out that fat injections may present a risk in patients with intraepithelial neoplasia. However, their study was retrospective, and-as the authors also emphasized - there was no one-to-one matching between the patient and control groups (59 lipofilling vs. 118 control). In order to reach such a conclusion of such wide-ranging, crucial importance, there is an obvious need for much more extensive data [92]. Thereafter, Gale et al. [93] performed another casecontrol study in 2015, in which they aimed to replicate the research of Petit et al. [91], using the same study design. They compared 211 patients who received fat grafting following treatment for breast cancer with a control group (422 patients). During a follow-up period of 32 months following fat grafting, they found no significant difference in the cancer recurrence rate compared with the control group. Petit et al. [94] published another clinical study in 2017, in which they compared 322 invasive breast cancer patients who had undergone lipoinjection with the same number of control group patients over a 4.6-year follow-up period. In comparison with their previous study, they increased the follow-up time and they individually matched the two groups. They did not observe any difference in the incidence of recurrent breast cancer (local recurrence, axillary node metastasis or distant metastases).

Myckatyn et al. [95] investigated 3,271 patients with stage IIII invasive ductal carcinomas who underwent fat grafting procedures. They found an equivalent risk of cancer recurrence in comparison with those who did not undergo a fat grafting procedure. Silva-Vergara et al. [96] followed up 205 patients who had undergone fat grafting for an 8-year period. They also found similar results.

Kronowitz et al. [97] suggested that hormonal therapy contributes to a tumor-forming environment between ADSCs and breast cancer cells. They found that the local recurrence rate increased three-fold in lipofilling patients who were receiving hormonal therapy. However, no similar results have been reported in other clinical studies.

From an oncological standpoint, we are presently unable to state that autologous fat grafting is a safe method. Therefore, further studies are needed to obtain more definitive findings. However, we can claim that there is no clear clinical evidence that fat grafting in breast reconstruction increases the risk of breast cancer $[9,17,33,40,85,88,95-99]$.

\section{Experimental studies}

The relationship between mature adipocytes and breast cancer cells has become a popular topic of scientific investigations in recent years. Adipose tissue has the potential to metabolize androgen to oestrogen through the expression of aromatase, which is produced by adipose tissue $[40,100]$. Due to this aromatase activity in adipose tissue, oestrogen levels in the breast tissue are 10 times higher than the levels in the blood. This increase is known to enhance the growth of breast cancer cells by a paracrine mechanism $[100,101]$. Furthermore, there is another mechanism, known as a paracrine loop, through which surrounding adipocytes enhance the growth of breast cancer cells. As the cancer grows, surrounding adipocytes increase the secretion of some endocrine factors and exhibit crucial transcriptional changes that also contribute to tumor cell growth [102]. In light of this information, experimental studies have increasingly focused on the relationship between adipose tissue and breast cancer in recent years.

As mentioned above, because of the obesity epidemic, the physiology of adipose tissue has received increased attention. In the two decades after the discovery of ADSCs, the relationship between ADSCs and breast cancer has also emerged as a focus. ADSCs can be easily harvested from white adipose tissue and they have multiple functions, including immunomodulation, antiapoptosis, angiogenesis and regeneration [103]. Because of these properties, $\mathrm{ADSC}$ s have been frequently thought to promote breast cancer development [104]. As shown in Table 2, multiple studies have demonstrated that stem cells originating from fat tissue support cancer formation. Nevertheless, other studies have shown that ADSCs may inhibit the growth of breast cancer $[105,106]$.

Yu et al. [37] reported that human adipocyte stem cells enhanced in vivo tumor growth when injected into an animal model. Walter et al. [44] also contributed to this line of research by showing that interleukin- 6 secreted by ADSCs plays an important role in the invasion and migration of breast cancer cells. Due to the increasing popularity of fat grafting in breast reconstruction, researchers have continued to question the reliability of fat grafts. Martin-Padura et al. [49] demonstrated that co-injection of human fat graft and $\mathrm{CD} 34^{+}$cells (white adipose tissue in humans is a rich reservoir of $\mathrm{CD} 34^{+}$cells) significantly increased tumor growth and metastases in breast cancer models. Kamat et al. [51] also showed that adipose-derived mesenchymal stromal cells have the potential to promote tumor progression in an in vitro study of breast cancer cells.

Since stem cell-enriched fat grafting is not frequently applied in breast reconstruction with fat grafting, Molto-Garcia et al. [52] compared the effects of fat grafts and enriched fat grafts on breast cancer. They demonstrated that autologous fat graft did not worsen the prognosis of breast cancer when used in the same way as is done routinely in clinical practice (breast conservation 
surgery). Additionally, Orbay et al. [54] highlighted the discrepancy between experimental and clinical studies in their recent study. According to their study, fat grafting is safe for oncological breast reconstruction, but stem cell-enriched fat grafting should be used only in patients with confirmed cancer remission.

In light of the studies mentioned above, we cannot conclude that the experimental studies have provided definitive results. It is also obvious that further studies are needed to clarify the relationship between breast cancer and fat grafting.

\section{RADIOLOGICAL FOLLOW-UP AFTER FAT GRAFTING}

An important question regarding radiological changes is whether only fat grafting leads to radiological changes which may be confused with cancer, or whether other widely accepted surgical modalities such as breast reduction cause similar changes. In the study conducted by Rubin et al. [10], the postoperative mammographic images of patients who had undergone augmentation mammaplasty through the CAL technique and patients who had reduction mammaplasty using the inferior or inferomedial pedicle technique were compared by eight radiologists with expertise in mammography. The results demonstrated that CAL did not present any additional difficulties compared to breast reduction for breast cancer monitoring. Similarly, although studies have investigated the radiological changes that occur due to breast reduction and breast implants, these methods are confidently used without any problems [17,107-113].

Another question relates to the method of radiological followup. It is very challenging to differentiate between benign and malignant lesions of the breast radiologically, and there are ongoing studies focusing on this point [114-116]. Three imaging methods are the main focus of these studies: mammography, ultrasonography (USG) and magnetic resonance imaging (MRI). Parikh et al. [115] developed a standardized classification system in order to distinguish between benign and malignant lesions on USG. Costantini et al. [114] compared USG, mammography and MRI, and they observed that after fat grafting, benign findings could be better detected through USG, whereas MRI is advantageous for detecting pathological lesions. Moreover, Pinell-White et al. [117] compared breast cancer patients who had undergone fat graft procedures to another group without fat grafts. According to their study, patients who had undergone a fat graft procedure required more breast imaging studies during the follow-up period (4.2 years) than the control group. However, they discovered that the suspicious areas that were found on imaging studies did not correspond to the areas of prior fat grafting. In other words, even though fat injection was not proven to increase the risk of breast cancer, it may cause radiological confusion during the follow-up period. According to another study [118] that investigated the effects of fat grafting after breast-conserving surgery, preoperative and postoperative (after $9 \pm 5$ months) radiographic changes were compared in patients who underwent fat grafting surgery. In their findings, postoperative imaging studies showed a higher rate of significant changes (such as fat cysts, calcifications, and scars) than preoperative findings. However, further studies are needed to clarify the longterm effects of fat grafting on radiological monitoring.

Radiological and clinical monitoring of the breast must be performed after all surgical interventions applied to the breast [17]. Although mammography is preferred by radiologists as a technique to distinguish between benign and malignant lesions, suspicious lesions should be re-evaluated using USG and MRI [17, $114,119,120]$. If suspicion remains, a biopsy must be performed without delay [17].

\section{CONCLUSION}

Fat grafting in breast surgery is a powerful tool for correcting asymmetries, and is also known to be a safe procedure. Patients who undergo breast augmentation with a fat graft for aesthetic purposes are not at an elevated risk for future breast cancer development. Other surgical procedures performed in the breast can also lead to radiological images that can be confused with breast cancer. In light of ongoing studies, the prediction that fat grafts will replace breast implants in the future is gaining greater traction.

Besides its use for aesthetic purposes, fat grafting in postmastectomy breast reconstruction has gained popularity in recent years, making it necessary to obtain adequate information about its reliability. Pluripotent stem cells, which have been known and studied for a long time, may contribute to the development of existing cancer cells. Thus, the application of fat grafts enriched with ADSCs to the breast may disrupt the microenvironment and the stromal-epithelial interactions. As a conclusion, although numerous experimental and clinical studies have investigated fat graft reliability, there is still no clear consensus on the oncological safety of fat grafting. Controlled postoperative studies with longer follow-up periods are needed in order to shed light on this issue.

\section{NOTES}

\section{Conflict of interest}

No potential conflict of interest relevant to this article was reported. 


\section{Author contribution}

Conceptualization: Bayram Y. Data curation: Sezgic M. Formal analysis: Bayram Y. Funding acquisition: Bozkurt M. Methodology: Karakol P. Project administration: Bayram Y. Visualization: Filinte GT. Writing - original draft: Bayram Y. Writing - review \& editing: Sezgic M. Approval of final manuscript: all authors.

\section{ORCID}

Yalcin Bayram https://orcid.org/0000-0002-1903-5903

Melihcan Sezgic https://orcid.org/0000-0002-8213-8526

Percin Karakol https://orcid.org/0000-0003-0068-2139

Mehmet Bozkurt https://orcid.org/0000-0002-4480-513X

Gaye Taylan Filinte https://orcid.org/0000-0003-2583-2922

\section{REFERENCES}

1. Neuber F. Fettransplantation. Chir Kongr Verhandl Dsch Gesellch Chir 1893;22:66.

2. Chan CW, McCulley SJ, Macmillan RD. Autologous fat transfer: a review of the literature with a focus on breast cancer surgery. J Plast Reconstr Aesthet Surg 2008;61: 1438-48.

3. Trojahn Kolle SF, Oliveri RS, Glovinski PV, et al. Importance of mesenchymal stem cells in autologous fat grafting: a systematic review of existing studies. J Plast Surg Hand Surg 2012;46:59-68.

4. Carpaneda CA, Ribeiro MT. Percentage of graft viability versus injected volume in adipose autotransplants. Aesthetic Plast Surg 1994;18:17-9.

5. Siegel RL, Miller KD, Jemal A. Cancer statistics, 2019. CA Cancer J Clin 2019;69:7-34.

6. Czerny A. Plastischer Ersatz der Brustdruse durch ein Lipoma. Chir Kongr Verhandl 1895;216:2.

7. Report on autologous fat transplantation. ASPRS Ad-Hoc Committee on New Procedures, September 30, 1987. Plast Surg Nurs 1987;7:140-1.

8. Khouri RK, Eisenmann-Klein M, Cardoso E, et al. Brava and autologous fat transfer is a safe and effective breast augmentation alternative: results of a 6-year, 81-patient, prospective multicenter study. Plast Reconstr Surg 2012;129: 1173-87.

9. Gutowski KA; ASPS Fat Graft Task Force. Current applications and safety of autologous fat grafts: a report of the ASPS fat graft task force. Plast Reconstr Surg 2009;124: 272-80.

10. Rubin JP, Coon D, Zuley M, et al. Mammographic changes after fat transfer to the breast compared with changes after breast reduction: a blinded study. Plast Reconstr Surg 2012;
129:1029-38.

11. Bernard RW, Beran SJ. Autologous fat graft in nipple reconstruction. Plast Reconstr Surg 2003;112:964-8.

12. Chajchir A, Benzaquen I. Liposuction fat grafts in face wrinkles and hemifacial atrophy. Aesthetic Plast Surg 1986; 10:115-7.

13. Wang G, Ren Y, Cao W, et al. Liposculpture and fat grafting for aesthetic correction of the gluteal concave deformity associated with multiple intragluteal injection of penicillin in childhood. Aesthetic Plast Surg 2013;37:39-45.

14. Rusciani Scorza A, Rusciani Scorza L, Troccola A, et al. Autologous fat transfer for face rejuvenation with tumescent technique fat harvesting and saline washing: a report of 215 cases. Dermatology 2012;224:244-50.

15. Yoshimura K, Sato K, Aoi N, et al. Cell-assisted lipotransfer for cosmetic breast augmentation: supportive use of adipose-derived stem/stromal cells. Aesthetic Plast Surg 2008; 32:48-55.

16. Zheng DN, Li QF, Lei H, et al. Autologous fat grafting to the breast for cosmetic enhancement: experience in 66 patients with long-term follow up. J Plast Reconstr Aesthet Surg 2008;61:792-8.

17. Coleman SR, Saboeiro AP. Fat grafting to the breast revisited: safety and efficacy. Plast Reconstr Surg 2007;119:77585.

18. Zocchi ML, Zuliani F. Bicompartmental breast lipostructuring. Aesthetic Plast Surg 2008;32:313-28.

19. Mu DL, Luan J, Mu L, et al. Breast augmentation by autologous fat injection grafting: management and clinical analysis of complications. Ann Plast Surg 2009;63:124-7.

20. Del Vecchio DA, Bucky LP. Breast augmentation using preexpansion and autologous fat transplantation: a clinical radiographic study. Plast Reconstr Surg 2011;127:2441-50.

21. Kamakura T, Ito K. Autologous cell-enriched fat grafting for breast augmentation. Aesthetic Plast Surg 2011;35:102230.

22. Serra-Renom JM, Munoz-Olmo J, Serra-Mestre JM. Endoscopically assisted aesthetic augmentation of tuberous breasts and fat grafting to correct the double bubble. Aesthetic Plast Surg 2012;36:1114-9.

23. Pinsolle V, Chichery A, Grolleau JL, et al. Autologous fat injection in Poland's syndrome. J Plast Reconstr Aesthet Surg 2008;61:784-91.

24. Salgarello M, Visconti G, Barone-Adesi L. Fat grafting and breast reconstruction with implant: another option for irradiated breast cancer patients. Plast Reconstr Surg 2012; 129:317-29.

25. Spear SL, Wilson HB, Lockwood MD. Fat injection to cor- 
rect contour deformities in the reconstructed breast. Plast Reconstr Surg 2005;116:1300-5.

26. Missana MC, Laurent I, Barreau L, et al. Autologous fat transfer in reconstructive breast surgery: indications, technique and results. Eur J Surg Oncol 2007;33:685-90.

27. Sarfati I, Ihrai T, Duvernay A, et al. Autologous fat grafting to the postmastectomy irradiated chest wall prior to breast implant reconstruction: a series of 68 patients. Ann Chir Plast Esthet 2013;58:35-40.

28. Chajchir A. Fat injection: long-term follow-up. Aesthetic Plast Surg 1996;20:291-6.

29. Niechajev I, Sevcuk O. Long-term results of fat transplantation: clinical and histologic studies. Plast Reconstr Surg 1994;94:496-506.

30. Lewis CM. The current status of autologous fat grafting. Aesthetic Plast Surg 1993;17:109-12.

31. Choi M, Small K, Levovitz C, et al. The volumetric analysis of fat graft survival in breast reconstruction. Plast Reconstr Surg 2013;131:185-91.

32. Rigotti G. Discussion: the volumetric analysis of fat graft survival in breast reconstruction. Plast Reconstr Surg 2013; 131:192-3.

33. Rosing JH, Wong G, Wong MS, et al. Autologous fat grafting for primary breast augmentation: a systematic review. Aesthetic Plast Surg 2011;35:882-90.

34. Gentile P, Di Pasquali C, Bocchini I, et al. Breast reconstruction with autologous fat graft mixed with platelet-rich plasma. Surg Innov 2013;20:370-6.

35. Locke MB, de Chalain TM. Current practice in autologous fat transplantation: suggested clinical guidelines based on a review of recent literature. Ann Plast Surg 2008;60:98-102.

36. Manabe Y, Toda S, Miyazaki K, et al. Mature adipocytes, but not preadipocytes, promote the growth of breast carcinoma cells in collagen gel matrix culture through cancerstromal cell interactions. J Pathol 2003;201:221-8.

37. Yu JM, Jun ES, Bae YC, et al. Mesenchymal stem cells derived from human adipose tissues favor tumor cell growth in vivo. Stem Cells Dev 2008;17:463-73.

38. Sasano H, Ozaki M. Aromatase expression and its localization in human breast cancer. J Steroid Biochem Mol Biol 1997;61:293-8.

39. Wang YY, Lehuede C, Laurent V, et al. Adipose tissue and breast epithelial cells: a dangerous dynamic duo in breast cancer. Cancer Lett 2012;324:142-51.

40. Pearl RA, Leedham SJ, Pacifico MD. The safety of autologous fat transfer in breast cancer: lessons from stem cell biology. J Plast Reconstr Aesthet Surg 2012;65:283-8.

41. Vona-Davis L, Rose DP. Adipokines as endocrine, para- crine, and autocrine factors in breast cancer risk and progression. Endocr Relat Cancer 2007; 14:189-206.

42. Park J, Euhus DM, Scherer PE. Paracrine and endocrine effects of adipose tissue on cancer development and progression. Endocr Rev 2011;32:550-70.

43. Iyengar P, Combs TP, Shah SJ, et al. Adipocyte-secreted factors synergistically promote mammary tumorigenesis through induction of anti-apoptotic transcriptional programs and proto-oncogene stabilization. Oncogene 2003; 22:6408-23.

44. Walter M, Liang S, Ghosh S, et al. Interleukin 6 secreted from adipose stromal cells promotes migration and invasion of breast cancer cells. Oncogene 2009;28:2745-55.

45. Ouchi N, Parker JL, Lugus JJ, et al. Adipokines in inflammation and metabolic disease. Nat Rev Immunol 2011;11: 85-97.

46. Hovey RC, McFadden TB, Akers RM. Regulation of mammary gland growth and morphogenesis by the mammary fat pad: a species comparison. J Mammary Gland Biol Neoplasia 1999;4:53-68.

47. Place AE, Jin Huh S, Polyak K. The microenvironment in breast cancer progression: biology and implications for treatment. Breast Cancer Res 2011;13:227.

48. Bochet L, Meulle A, Imbert S, et al. Cancer-associated adipocytes promotes breast tumor radioresistance. Biochem Biophys Res Commun 2011;411:102-6.

49. Martin-Padura I, Gregato G, Marighetti P, et al. The white adipose tissue used in lipotransfer procedures is a rich reservoir of CD34+ progenitors able to promote cancer progression. Cancer Res 2012;72:325-34.

50. Rahimi N, Saulnier R, Nakamura T, et al. Role of hepatocyte growth factor in breast cancer: a novel mitogenic factor secreted by adipocytes. DNA Cell Biol 1994;13:1189-97.

51. Kamat P, Schweizer R, Kaenel P, et al. Human adipose-derived mesenchymal stromal cells may promote breast cancer progression and metastatic spread. Plast Reconstr Surg 2015;136:76-84.

52. Molto-Garcia R, Gonzalez-Alonso V, Villaverde-Domenech $\mathrm{ME}$, et al. Effect of human fat graft on breast cancer metastasis in a murine model. Plast Reconstr Surg 2017;139: 1119-28.

53. Tsuji W, Valentin JE, Marra KG, et al. An animal model of local breast cancer recurrence in the setting of autologous fat grafting for breast reconstruction. Stem Cells Transl Med 2018;7:125-34.

54. Orbay H, Hinchcliff KM, Charvet HJ, et al. Fat graft safety after oncologic surgery: addressing the contradiction between in vitro and clinical studies. Plast Reconstr Surg 2018; 
142:1489-99.

55. Wu J, Bostrom P, Sparks LM, et al. Beige adipocytes are a distinct type of thermogenic fat cell in mouse and human. Cell 2012;150:366-76.

56. Lafontan M. Historical perspectives in fat cell biology: the fat cell as a model for the investigation of hormonal and metabolic pathways. Am J Physiol Cell Physiol 2012;302: C327-59.

57. Shapiro B, Wertheimer E. The synthesis of fatty acids in adipose tissue in vitro. J Biol Chem 1948;173:725-8.

58. Lindroos B, Suuronen R, Miettinen S. The potential of adipose stem cells in regenerative medicine. Stem Cell Rev Rep 2011;7:269-91.

59. Schaffler A, Scholmerich J, Buechler C. Mechanisms of disease: adipokines and breast cancer - endocrine and paracrine mechanisms that connect adiposity and breast cancer. Nat Clin Pract Endocrinol Metab 2007;3:345-54.

60. Pierobon M, Frankenfeld CL. Obesity as a risk factor for triple-negative breast cancers: a systematic review and meta-analysis. Breast Cancer Res Treat 2013;137:307-14.

61. Ligibel J. Obesity and breast cancer. Oncology (Williston Park) 2011;25:994-1000.

62. Gu JW, Young E, Patterson SG, et al. Postmenopausal obesity promotes tumor angiogenesis and breast cancer progression in mice. Cancer Biol Ther 2011;11:910-7.

63. Kerr J, Anderson C, Lippman SM. Physical activity, sedentary behaviour, diet, and cancer: an update and emerging new evidence. Lancet Oncol 2017; 18:e457-71.

64. Matthews SB, Thompson HJ. The obesity-breast cancer conundrum: an analysis of the issues. Int J Mol Sci 2016; 17:E989.

65. Yang H, Youm YH, Vandanmagsar B, et al. Obesity increases the production of proinflammatory mediators from adipose tissue $\mathrm{T}$ cells and compromises TCR repertoire diversity: implications for systemic inflammation and insulin resistance. J Immunol 2010;185:1836-45.

66. Trayhurn P, Wood IS. Signalling role of adipose tissue: adipokines and inflammation in obesity. Biochem Soc Trans 2005;33(Pt 5):1078-81.

67. Arita Y, Kihara S, Ouchi N, et al. Paradoxical decrease of an adipose-specific protein, adiponectin, in obesity. Biochem Biophys Res Commun 1999;257:79-83.

68. Ohashi K, Parker JL, Ouchi N, et al. Adiponectin promotes macrophage polarization toward an anti-inflammatory phenotype. J Biol Chem 2010;285:6153-60.

69. Guo J, Widgerow AD, Banyard D, et al. Strategic sequences in fat graft survival. Ann Plast Surg 2015;74:376-82.

70. Zuk PA, Zhu M, Mizuno H, et al. Multilineage cells from human adipose tissue: implications for cell-based therapies. Tissue Eng 2001; 7:211-28.

71. Moseley TA, Zhu M, Hedrick MH. Adipose-derived stem and progenitor cells as fillers in plastic and reconstructive surgery. Plast Reconstr Surg 2006;118(3 Suppl):121S-8S.

72. Strem BM, Hicok KC, Zhu M, et al. Multipotential differentiation of adipose tissue-derived stem cells. Keio J Med 2005;54:132-41.

73. Zuk PA, Zhu M, Ashiian P, et al. Human adipose tissue is a source of multipotent stem cells. Mol Biol Cell 2002;13: 4279-95.

74. Seo MJ, Suh SY, Bae YC, et al. Differentiation of human adipose stromal cells into hepatic lineage in vitro and in vivo. Biochem Biophys Res Commun 2005;328:258-64.

75. Fraser JK, Schreiber RE, Zuk PA, et al. Adult stem cell therapy for the heart. Int J Biochem Cell Biol 2004;36:658-66.

76. Jack GS, Almeida FG, Zhang R, et al. Processed lipoaspirate cells for tissue engineering of the lower urinary tract: implications for the treatment of stress urinary incontinence and bladder reconstruction. J Urol 2005;174:20415.

77. Case J, Horvath TL, Howell JC, et al. Clonal multilineage differentiation of murine common pluripotent stem cells isolated from skeletal muscle and adipose stromal cells. Ann N Y Acad Sci 2005;1044:183-200.

78. Casteilla L, Planat-Benard V, Cousin B, et al. Plasticity of adipose tissue: a promising therapeutic avenue in the treatment of cardiovascular and blood diseases? Arch Mal Coeur Vaiss 2005;98:922-6.

79. Fortier LA. Stem cells: classifications, controversies, and clinical applications. Vet Surg 2005;34:415-23.

80. Vacanti V, Kong E, Suzuki G, et al. Phenotypic changes of adult porcine mesenchymal stem cells induced by prolonged passaging in culture. J Cell Physiol 2005;205:194201.

81. Aust L, Devlin B, Foster SJ, et al. Yield of human adiposederived adult stem cells from liposuction aspirates. Cytotherapy 2004;6:7-14.

82. Guilak F. Functional tissue engineering: the role of biomechanics in reparative medicine. Ann N Y Acad Sci 2002; 961:193-5.

83. Sundelacruz S, Kaplan DL. Stem cell- and scaffold-based tissue engineering approaches to osteochondral regenerative medicine. Semin Cell Dev Biol 2009;20:646-55.

84. Waked K, Colle J, Doornaert M, et al. Systematic review: the oncological safety of adipose fat transfer after breast cancer surgery. Breast 2017;31:128-36.

85. Petit JY, Botteri E, Lohsiriwat V, et al. Locoregional recur- 
rence risk after lipofilling in breast cancer patients. Ann Oncol 2012;23:582-8.

86. Delay E, Garson S, Tousson G, et al. Fat injection to the breast: technique, results, and indications based on 880 procedures over 10 years. Aesthet Surg J 2009;29:360-76.

87. Illouz YG, Sterodimas A. Autologous fat transplantation to the breast: a personal technique with 25 years of experience. Aesthetic Plast Surg 2009;33:706-15.

88. Claro F Jr, Figueiredo JC, Zampar AG, et al. Applicability and safety of autologous fat for reconstruction of the breast. Br J Surg 2012;99:768-80.

89. Seth AK, Hirsch EM, Kim JY, et al. Long-term outcomes following fat grafting in prosthetic breast reconstruction: a comparative analysis. Plast Reconstr Surg 2012;130:984-90.

90. Petit JY, Lohsiriwat V, Clough KB, et al. The oncologic outcome and immediate surgical complications of lipofilling in breast cancer patients: a multicenter study: Milan-Paris-Lyon experience of 646 lipofilling procedures. Plast Reconstr Surg 2011;128:341-6.

91. Petit JY, Rietjens M, Botteri E, et al. Evaluation of fat grafting safety in patients with intraepithelial neoplasia: a matched-cohort study. Ann Oncol 2013;24:1479-84.

92. Regolo L, Galli L, Petrolo G, et al. Short commentaries on data published by Petit et al. on locoregional risk after lipofilling in breast cancer patients. Breast 2013;22:96-7.

93. Gale KL, Rakha EA, Ball G, et al. A case-controlled study of the oncologic safety of fat grafting. Plast Reconstr Surg 2015;135:1263-75.

94. Petit JY, Maisonneuve P, Rotmensz N, et al. Fat grafting after invasive breast cancer: a matched case-control study. Plast Reconstr Surg 2017;139:1292-6.

95. Myckatyn TM, Wagner IJ, Mehrara BJ, et al. Cancer risk after fat transfer: a multicenter case-cohort study. Plast Reconstr Surg 2017;139:11-8.

96. Silva-Vergara C, Fontdevila J, Weshahy O, et al. Breast cancer recurrence is not increased with lipofilling reconstruction: a case-controlled study. Ann Plast Surg 2017;79:243-8.

97. Kronowitz SJ, Mandujano CC, Liu J, et al. Lipofilling of the breast does not increase the risk of recurrence of breast cancer: a matched controlled study. Plast Reconstr Surg 2016;137:385-93.

98. Rigotti G, Marchi A, Stringhini P, et al. Determining the oncological risk of autologous lipoaspirate grafting for postmastectomy breast reconstruction. Aesthetic Plast Surg 2010;34:475-80.

99. Rietjens M, De Lorenzi F, Rossetto F, et al. Safety of fat grafting in secondary breast reconstruction after cancer. J Plast Reconstr Aesthet Surg 2011;64:477-83.
100. Wang X, Simpson ER, Brown KA. Aromatase overexpression in dysfunctional adipose tissue links obesity to postmenopausal breast cancer.J Steroid Biochem Mol Biol 2015; 153:35-44.

101. Sasaki Y, Miki Y, Hirakawa H, et al. Immunolocalization of estrogen-producing and metabolizing enzymes in benign breast disease: comparison with normal breast and breast carcinoma. Cancer Sci 2010;101:2286-92.

102. Ghosh S, Dean A, Walter M, et al. Cell density-dependent transcriptional activation of endocrine-related genes in human adipose tissue-derived stem cells. Exp Cell Res 2010; 316:2087-98.

103. Caplan AI, Correa D. The MSC: an injury drugstore. Cell Stem Cell 2011;9:11-5.

104. Smalley M, Ashworth A. Stem cells and breast cancer: a field in transit. Nat Rev Cancer 2003;3:832-44.

105. Sun B, Roh KH, Park JR, et al. Therapeutic potential of mesenchymal stromal cells in a mouse breast cancer metastasis model. Cytotherapy 2009;11:289-98.

106. Senst C, Nazari-Shafti T, Kruger S, et al. Prospective dual role of mesenchymal stem cells in breast tumor microenvironment. Breast Cancer Res Treat 2013;137:69-79.

107. Brown FE, Sargent SK, Cohen SR, et al. Mammographic changes following reduction mammaplasty. Plast Reconstr Surg 1987;80:691-8.

108. Isaacs $G$, Rozner L, Tudball C. Breast lumps after reduction mammaplasty. Ann Plast Surg 1985;15:394-9.

109. Miller CL, Feig SA, Fox JW. Mammographic changes after reduction mammoplasty. AJR Am J Roentgenol 1987;149: 35-8.

110. Sickles EA, Herzog KA. Mammography of the postsurgical breast. AJR Am J Roentgenol 1981;136:585-8.

111. Redfern AB, Ryan JJ, Su TC. Calcification of the fibrous capsule about mammary implants. Plast Reconstr Surg 1977;59:249-51.

112. Benjamin JL, Guy CL. Calcification of implant capsules following augmentation mammaplasty: case report. Plast Reconstr Surg 1977;59:432-3.

113. Koide T, Katayama H. Calcification in augmentation mammoplasty. Radiology 1979;130:337-40.

114. Costantini M, Cipriani A, Belli P, et al. Radiological findings in mammary autologous fat injections: a multi-technique evaluation. Clin Radiol 2013;68:27-33.

115. Parikh RP, Doren EL, Mooney B, et al. Differentiating fat necrosis from recurrent malignancy in fat-grafted breasts: an imaging classification system to guide management. Plast Reconstr Surg 2012;130:761-72.

116. Veber M, Tourasse C, Toussoun G, et al. Radiographic 
findings after breast augmentation by autologous fat transfer. Plast Reconstr Surg 2011;127:1289-99.

117. Pinell-White XA, Etra J, Newell M, et al. Radiographic implications of fat grafting to the reconstructed breast. Breast J 2015;21:520-5.

118. Juhl AA, Redsted S, Engberg Damsgaard T. Autologous fat grafting after breast conserving surgery: breast imaging changes and patient-reported outcome. J Plast Reconstr Aesthet Surg 2018;71:1570-6.
119. Chen SC, Cheung YC, Su CH, et al. Analysis of sonographic features for the differentiation of benign and malignant breast tumors of different sizes. Ultrasound Obstet Gynecol 2004;23:188-93.

120. Pulagam SR, Poulton T, Mamounas EP. Long-term clinical and radiologic results with autologous fat transplantation for breast augmentation: case reports and review of the literature. Breast J 2006;12:63-5. 